\title{
How to Queer the Past Without Sex: Queer Theory, Feminisms and the Archaeology of Identity
}

Chelsea Blackmore, Department of Anthropology, University of California, Santa Cruz, 361 Social Sciences 1, Santa Cruz, CA 95064, USA

E-mail: cblackmo@ucsc.edu

\section{ABSTRACT}

A queer archaeology is often equated to looking for ancient homosexuality. As a challenge to heteronormative practice, queer theory, instead, provides a framework for engaging with all aspects of identity formation and the processes and behaviors that mediate it. This article examines two primary points: (1) queer theory's relationship to feminist practice and archaeology and (2) its application to the construction and production of difference among ancient Maya commoners. Through this analysis, I explore how investigations of identity and status can and should be part of a queer analysis. Work at the Northeast Group, part of the site of Chan, Belize illustrates how focus on internal class composition, specifically change through time, "queers" traditional models of ancient Maya class formation.

Résumé: Le concept d'archéologie allosexuelle (queer, en Anglais) est souvent assimilé à la recherche de l'homosexualité dans l'antiquité. Remettant en cause les pratiques hétéronormatives, la théorie allosexuelle propose plutôt un cadre permettant d'aborder tous les aspects de la formation de l'identité ainsi que les processus et les comportements qui en sont les médiateurs. Cet article examine deux points: 1. la relation de la théorie allosexuelle aux pratiques féministes et à l'archéologie, et 2 . son application à la construction et à la production de différence chez l'ancien peuple Maya. Au travers de cette analyse, j'explore les raisons pour lesquelles les recherches sur l'identité et le statut peuvent et doivent être intégrées à une analyse allosexuelle. Le travail au Northeast Group, qui constitue une partie du site de Chan au Bélize, illustre comment la focalisation sur la composition interne des classes, et plus particulièrement son évolution, "allosexualise»les modèles traditionnels de formation des classes chez les anciens Mayas. 
Resumen: Cuando se habla de arqueología de la homosexualidad se la imagina a menudo buscando homosexualidad ancestral. En cambio, como reto para la práctica heteronormativa, la teoría de la homosexualidad proporciona un marco para abordar todos los aspectos de la formación de identidades, así como los procesos y los comportamientos que median en ella. En este artículo se analizan dos puntos: 1. la relación de la teoría de la homosexualidad con la práctica y la arqueología feminista y; 2. su aplicación en la interpretación y la producción de las diferencias entre los antiguos plebeyos mayas. A través de este análisis, analizo por qué las investigaciones de identidad y de estatus pueden y deberían formar parte de un análisis sobre homosexualidad. Los trabajos en el Grupo del Noroeste, que forma parte del yacimiento de Chan en Belice demuestran que el enfoque en la composición interna de clases modifica a través del tiempo los modelos tradicionales homosexuales de la formación de clase de los antiguos mayas.

\section{KEY WORDS}

Queer theory, Identity, Poststructural feminism, Ancient Maya

Feminist theory has played a profound role in reshaping archaeological practice, not only through the questions we ask but in the methodologies we employ. Over the years, its boundaries have been stretched, variously influenced by postmodern and poststructural theory as well as the radical critiques of women of color and lesbian feminists. Earlier "add women and stir" models have given way to research agendas that recognize the multivocality of gendered identities. The denaturalization of these in terms of sex and sexuality has come to the forefront of archaeological investigations only recently, largely through the application of queer theory.

Commonly associated with the "origins of homosexuality", a queer archaeology is much more than a historical lesson in sexual difference (Dowson 1998; Voss and Schmidt 2000; Voss 2000). While it can and should challenge heteronormative assumptions, queer theory has the potential to illuminate many processes in the past, not just those related to sexuality. As a tool for deconstructing the normative, it provides a framework for archaeologists to examine identity and the processes and behaviors that inform it (Ardren 2008; Voss 2008; Wylie 2004). While fluidity and plurality are easily conceived in a modern context, most examinations of prehistoric identity formation focus on one aspect of identity to the near exclusion of others. Queering identity, in contrast, necessitates an 
understanding of social positionality-the composite of IDENITIES that make up any one individual.

Although recent work in feminist archaeology draws from poststructuralism and postmodernism, queer theory remains underutilized despite extensive publications and conference symposia. Such disregard, whether willful or not, is unsettling given its potential to reframe archaeological discussions of identity as complex, situational and contextual. I examine how queer theory, as part of feminist discourse, informs archaeological research, particularly in the realm of ancient Maya identity formation. My discussion will be divided into two sections: (1) queer theory's relationship to feminist practice and archaeology and (2) its application to the construction and production of difference among ancient Maya commoners at the site of Chan, Belize. Does the utilization of queer theory require an examination of either gender or sexuality? If not, how are such investigations applicable to or a product of queer analyses? Work at the Northeast Group, part of the site of Chan, Belize illustrates how a focus on internal class composition, specifically change through time, "queers" traditional models of ancient Maya class formation.

\section{Queer Theory and Feminist Archaeology}

Queer theory draws on numerous intellectual and political strands-poststructural/postmodern feminisms, lesbian and gay history, sexology, AIDS activism, and Queer liberation movements (Sullivan 2003). As a word, queer references "whatever is at odds with the normal, the legitimate, the dominant" (Halperin 1995:62). This alone, however does not reflect the power and utility of queer as a theoretical tool:

'Queer'... describes a horizon of possibility whose precise extent and heterogeneous scope cannot in principle be delineated in advance. It is from the eccentric positionality occupied by the queer subject that it may become possible to envision a variety of possibilities for reordering the relations among sexual behaviors, erotic identities, constructions of gender, forms of knowledge, regimes of enunciation, logics of representation, modes of self-constitution, and practices of community-for restructuring, that is, the relations among power, truth, and desire. (Halperin 1995:62-63)

The queer movement challenges the very ideas of normality which underpin social institutions and practices. From a queer perspective nothing is natural, nothing is normal. Everything is a social and cultural construct and gender identities are acquired, at least in part, through performance...In theoretical terms, queer theory is in many ways postmodern, since it renounces any fixed notions of difference...Binary oppositions are replaced by a proliferation of 
differences which queer theory and politics refuses to hierarchize. (Weedon 1999:73)

In these contexts, queer becomes a verb, the very act of deconstructing or at least questioning the categories and methodologies naturalized within scholarly discourse. Queer as a theoretical tool formalized amongst debates concerning then definitions of gender, sex, and sexuality (see Butler 1990, 1993; de Lauretis 1991; Foucault 1978; Grosz 1994; Halperin 1995; Sedgwick 1990). As Rubin (1984:307) notes, sexuality was reduced to the act of sex, and more specifically a function of male-female relations. Not only did this reinforce a heteronormative perspective, but illustrated that feminist studies of the time were not an adequate site for theorizing sexuality and sexual oppression (Rubin ibid:309). Butler (1993) elaborates on this point, arguing that both gender and sexual identities were cultural constructions. Sexual differences, in particular, were part of highly regulated gender performances that served in the "consolidation of the heterosexual imperative" (ibid:2). In this light, gender and sexual identities could no longer be framed as constant, stable, or irreducible truths.

Although the anti-essentialism at the heart of queer theory parallels many of the central tenants and principles of feminism, the two have a long and contentious history (Dowson 2007; Rudy 2000; Weedon 1999). As Voss (2000:130) notes, queer theory's focus on the deconstruction of gender and sexuality represents a direct challenge to a feminist practice concerned with legitimizing gender studies. This focus along with queer theory's aggressive political stance have had specific sexist implications as well: "To be queer often means to be public, hard, aggressive, "in-yourface"; those attributes historically associated with women which reproduce children and daily life are sometimes dismissed as soft and accommodationist by the new queer discourse" (Rudy 2000:207). While these conflicts arose directly out of the exclusionary identity politics of the 80 's and 90 's, continued intellectual engagement with other forms of feminism and critical social theory have blurred these ideological and political boundaries. In particular, critiques by transnational, lesbian, and indigenous feminists argue that discussions of gender and sexuality fail to consider the articulation of other forms of oppression, like race, ethnicity, and class (Anzaldúa 1991; Barnard 1999; Hammonds 1997; Harding 1991; Moraga 1996; Nagel 2000; Namaste 1996; Zinn and Dill 1996). This work reframes discussion of gender and sexuality in terms of intersectionality: "the complex interaction between a range of discourses, institutions, identities, and forms of exploitation that structure subjectivities (and the relations between them) in elaborate, heterogeneous, and often contradictory ways" (Sullivan 2003:72). It is within these spaces that the overlapping concerns of queer theory and feminist theory become a productive point of engagement 
(Rudy 2000). Moreover a focus on intersectionality provides a way to understand fluidity and historical contingency important to queer theory without ignoring the structurally embedded practices of power at the core of feminist philosophy.

In terms of feminist archaeology, queer theory has gained momentum over the last 10 years (Alberti 2001; Ardren 2008; Casella 2000; Croucher 2005; Dowson 2000, 2007; Hays-Gilpin 2004; Hollimon 1997; Schmidt 2002; Schmidt and Voss 2000; Voss 2005, 2008). While a common tool in theorizing "the feminist archaeological project" (Voss 2000, eg. Ortner and Whitehead 1981), anthropological archaeology was slow to investigate sexuality. Joyce (2004:87) notes experiences of sexuality and gender were displaced by structural analyses that perceived differences in terms of fixed social and political positioning. As a response to this rigidity, scholars influenced heavily by the work of Judith Butler $(1990,1993)$ and Michele Foucault (1978), began emphasizing material culture in terms of representation, embodiment, and performativity-moving beyond assumptions of apriori identity to one where material remains were a mediation between self and society (Alberti 2001; Casella and Fowler 2005; Perry and Joyce 2001; Joyce 2000, 2004, 2005a; Loren 2001; Meskell 1999, 2007; Meskell and Joyce 2003; Strassburg 2000). This work demonstrates how archaeological bodies, whether we refer to the skeletons themselves, their adornment, or graphic representations, are in a constant process of construction, negotiation, and deconstruction. In this framework, objects cannot be viewed as mere reflections of the past, but rather fragments embedded in a recursive dialogue with the world around it.

Despite these extensive publications, there continues to be a disconnect between queer theory and feminist archaeology (let alone the discipline at large). This problem arises, in large part, from assumptions of what queer theory is and its translatability to material analysis. Because queer theory is situated within a modern context, this has discouraged archaeologists from approaching and incorporating this theoretical perspective within their work (for exceptions see Dowson 2000; Perry and Joyce 2001; Voss 2000; Voss and Schmidt 2000). The difficulties of bridging concepts of modernity to archaeological materials, however, are not insurmountable if we look to similar challenges faced by feminist archaeologists 20 years ago. Additionally, the political and social connotations associated with queer have led many to associate it with a search for homosexuality. While examinations of alternate sexualities and gender categories are a necessary part of archaeological inquiry, they are not the only form of a queered analysis. Rather, queer theory's impact is in its potential to disrupt ALL normative archaeological practice, not just those related to sex, sexuality, and gender (Croucher 2005:611). As a postmodern critique of fixity and the normalization of categories, it provides a substantive framework for analyzing difference, 
regardless of time period, culture area, or material assemblage (Weedon 1999; see also Ardren 2008; Wylie 2004).

In the next section, I consider how queer theory can be applied to the deconstruction of ancient Maya commoner identity. As a state-level society, the ancient Maya were enmeshed in multiple levels of social organization, including political factions, social class, gender, status, lineage, occupation, and ethnicity. As contradictory and overlapping processes, archaeologists rarely examine these in terms of class positionality, specifically the way in which lower class (eg. "commoner") identity is embedded within other social processes. Queer theory is uniquely positioned to examine these issues, by interrogating not only the modern biases that underwrite assumptions of commoner life but to explore social identity as fluid and contextual.

\section{Commoner Identities: A Case Study from Chan, Belize}

For Maya archaeology, feminist practice has led to an increasing interest in ancient households and the everyday lives of people. As Robin notes (2003:307), household archaeology places "people and their practices and differences at the center of archaeological interpretations of the past, rather than subsuming these into the 'noise' of passive and depersonalized depictions of ancient social systems." This focus highlights the considerable diversity that existed between people and communities, not only in their interactions but in the organization of local economies, residential patterns, and political structures (Gonlin 1994; Iannone and Connell 2003; Lohse and Valdez 2004; Robin 2003). My own research has questioned the normalization of "commoner" within archaeological interpretations of ancient Maya social organization (Blackmore 2007, 2008, in press). Specifically, how were differences in social identity and status expressed by peoples living at the Northeast Group?

To answer this question, I undertook research at the Northeast Group, one of several Late Classic (AD 600-900) settlements identified at the site of Chan, Belize (Figures 1 and 2). Chan was an ancient agrarian village located in the Upper Belize River Valley, approximately $4 \mathrm{~km}$ southeast of the minor polity-center of Xunantunich (Robin 1999). The Belize Valley's proximity to the urban center of Naranjo places it within the sphere of Petén politics (Ashmore and Leventhal 1993; Ball and Taschek 1991; Martin and Grube 2000). As the paramount center, Naranjo was the primary economic and political force in the region, impacting the growth and expansion of centers throughout the Belize Valley. Xunantunich was situated strategically along the Mopan River, an important waterway facilitating trade and communication with Classic period polities located between 


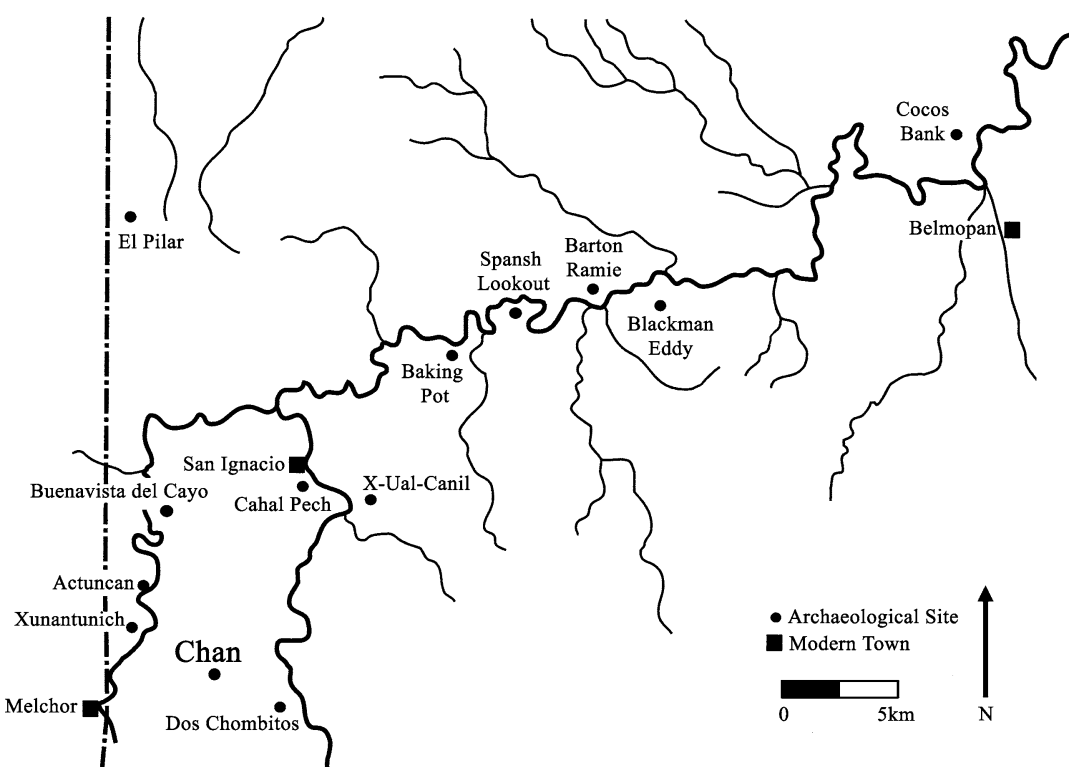

Figure 1. Location of Chan Archaeological Site (redrawn from Chase and Garber 2004) $X$

the Caribbean and the Petén. Unlike sites that flourished under Naranjo's protection, Xunantunich came to prominence after Naranjo's decline (Ashmore and Leventhal 1993; LeCount et al. 2002; Leventhal and Ashmore 2004). In a similar manner, Xunantunich's rise in the Late Classic (A.D. 600-A.D. 900) affected the social and political landscape of surrounding communities, like that of Chan. Work conducted by the Xunantunich Settlement Survey project illustrated that these settlements, while tied to the fortunes of Xunantunich were not completely dependent on them. While population density at Chan drops off after the fall of Xunantunich, people continued to live, work, and worship there (Docster et al. 2008).

Current work at Chan, directed by Cynthia Robin of Northwestern University, is part of a multiyear project concerned with establishing a diachronic perspective of site development, Chan's settlement and social heterogeneity, and the role its members played in the social and political processes of the Belize Valley (Robin et al. 2003, 2005, 2008; see also Wyatt 2004, 2008). Occupied from the Early Classic to the Terminal Classic period, the Northeast Group is characterized by 6 mound groups (NE \#1-6) and 2 isolated mounds (NE \#7-8), with buildings ranging in size from $.5 \mathrm{~m}$ to $2.0 \mathrm{~m}$ in height (see Figure 2). Ceramic chronology dates its apogee to the Late Classic period (A.D. 600-830), although two structures NE1 and NE-6 were founded in the Early Classic (A.D. 200-600). This settle- 


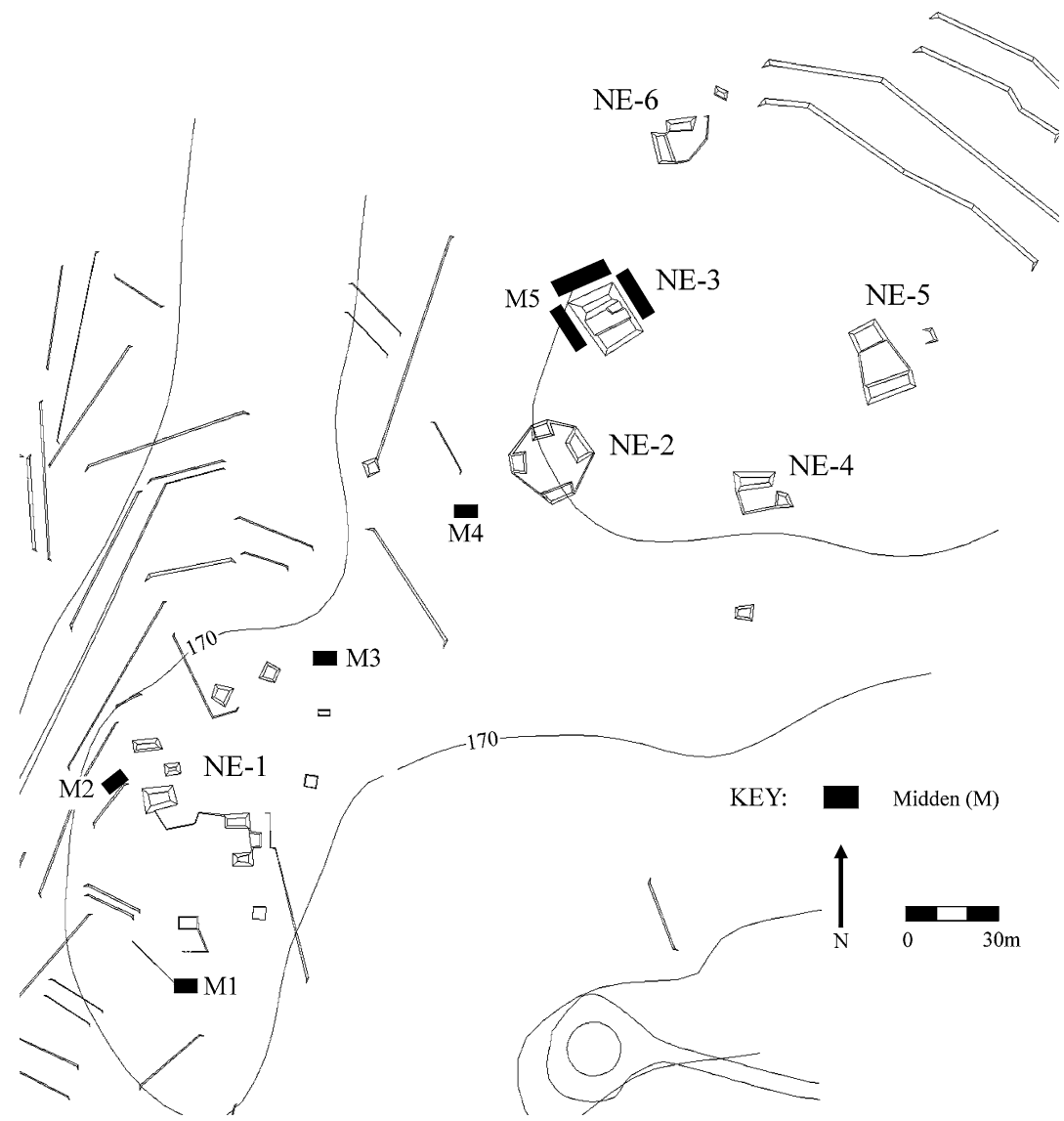

Figure 2. The Northeast Group (map courtesy of C. Robin) X

ment trajectory parallels population growth throughout the Chan site and in neighboring regions in the area, partly a residue of the growth of Xunantunich (Robin 2004).

Research and analysis was carried out over five field seasons, from 2003 to 2008. Work began with survey and testing of both on and off-mound areas to define the extent of each household group and identify the distribution of artifacts, activity areas, and architecture throughout the neighborhood. Based on analysis of materials recovered from this phase, later excavations focused on penetrating and horizontal excavations to examine the range and variability of households across the neighborhood (Blackmore 2007, 2008). To understand the complexity of identity construction, I examine the social history and material practices of three households, NE-1, NE-3, and NE-6. 


\section{Early Classic (AD 250-600)}

NE- 1 and NE- 6 are on two ends of the settlement area, NE-6 to the Northeast and NE-1 along its western extent. The settlement of both of these household groups may be associated with the steep hill sides that define the northern and western boundaries of the NE Group, areas that were intensively terraced for agricultural production. Both household groups began as single phase constructions-NE-1 (Structure 6), a $20 \mathrm{~cm}$ high, platform with an adjacent patio surface, and NE-6, a $50 \mathrm{~cm}$ high patio/ plaza surface. When comparing ceramics between the two, there is a notable distinction in form between open (bowls, plates, and dishes), closed (jars and tecomates), and specialized vessels (incense burners, drums). At NE- 1 , there is a relatively equal distribution between the open (51\%) and closed forms (43\%), with specialized sherds, all identified as incense burner fragments, making up the remaining $6 \%$. The assemblage from NE- 6 , in contrast, is comprised largely of closed forms, constituting $75 \%$ of identifiable ceramic fragments. While only $24 \%$ of the assemblage was of the open form including a number of large cauldrons. While common to Early Classic ceramic assemblages, these thick walled cooking vessels were found only in association with NE-6.

\section{Early Late Classic (AD 600-670)}

By the beginning of the Late Classic, occupants of NE-1 and NE-6 continue construction, elaborating the size and extent of each household group. At NE-6, a $40 \mathrm{~cm}$ high platform (Structure 2) was built overlying the earlier patio/plaza floor. A single-course crypt was identified at the base of construction, suggesting it was interred prior to the addition of Structure 2.

NE-1 construction extended the width of the earlier platform. At its widest, it measured $5.8 \mathrm{~m}$ running north-south, while adding $10 \mathrm{~cm}$ in height ( $30 \mathrm{~cm}$ total). Like NE-6, a single burial was found in association with this phase. Although it sits on bedrock (as did Phase 1 construction), I argue that it was not interred until the Early Late Classic period. Ceramics recovered from the surrounding matrix were dated to the Late Classic period. Further, the plaster surface associated with Phase 1 construction was poorly preserved above the burial whereas the same floor a meter north was in good condition. The burial was likely placed prior to Phase 2 construction, forcing occupants to cut through the earlier surface. This was then capped with fill and re-plastered.

A new household group, NE-3, was also founded during this time. Spatially, this group falls into an approximate middle of NE-1 and NE-6. Its 
first phase is characterized by a low-lying, rectangular platform, measuring $40 \mathrm{~cm}$ in height. This phase was marked by the deposition of Burial C6, a $65 \mathrm{~cm}$ deep cist cut into bedrock below Phase 1's living surface.

\section{Late Late Classic (AD 670-830)}

During the Late Late Classic, a series of middens formed, five across the neighborhood. Five middens were identified as a result of posthole testing: three (Middens 1, 2, and 3) in association with NE-1 and two located elsewhere in the neighborhood (see Figure 2). Ceramic material from these middens date to the Late Late Classic period. Of more interest, however, was the composition and extent of these various middens. Middens 1, 3, and 4 were relatively shallow and were not directly associated with architecture. Middens 2 and 5, on the other hand, were directly associated with architecture. Based on postholes, Midden 5 extended along the northern, eastern, and western faces of NE-3, with its densest concentration along it western edge. In contrast, Midden 2 was a tightly bound feature associated with the western edge of the NE-1 patio group excavated. Further excavations revealed that Middens 2 and 5 contained a considerable diversity of material when compared to the other middens identified (Blackmore 2008).

Analysis of ceramic form and function illustrates potential differences in the residue of practices associated with the nearby architectural groups. Based on LeCount's (2001) examination of feasting materials at Xunantunich, I compared the distribution of serving wares (plates, dishes, tecomates, and small bowls) to items associated with cooking and food preparation items (jars and large bowls). While the latter category comprises the majority of ceramic forms for all three groups, NE-3 had the highest concentration of serving wares at $30 \%$ ( $21 \%$ for NE-1 and NE-6) (Figure 3). This is reinforced by the distribution of finer, more decorative ceramics at NE-3, including Silk Grass Fluted, Martin's Incised, Gallinero Fluted, or Macal Orange. Additionally the only two vases identified for the neighborhood came from NE-3: one Martin's Incised vase and 1 Benque Viejo vase (see Gifford 1976).

Construction took off at both NE-1 and NE-3. For NE-1, this includes three additional construction episodes that elaborated the height and width of Structure 6. Terminal construction culminated in a $1.2 \mathrm{~m}$ high rectangular platform with three, $25 \mathrm{~cm}$ high benches built along its summit. At some later date, the patio was resurfaced, overlying the plaster associated with Structure 6's terminal architecture. Around the time of resurfacing occupants built Structure 4, a square, single-level platform $(4.5 \mathrm{~m} \times 4.5 \mathrm{~m})$ with a 3 -course staircase. This structure changed the spatial layout of the 
ood Prep

Serving Vessels

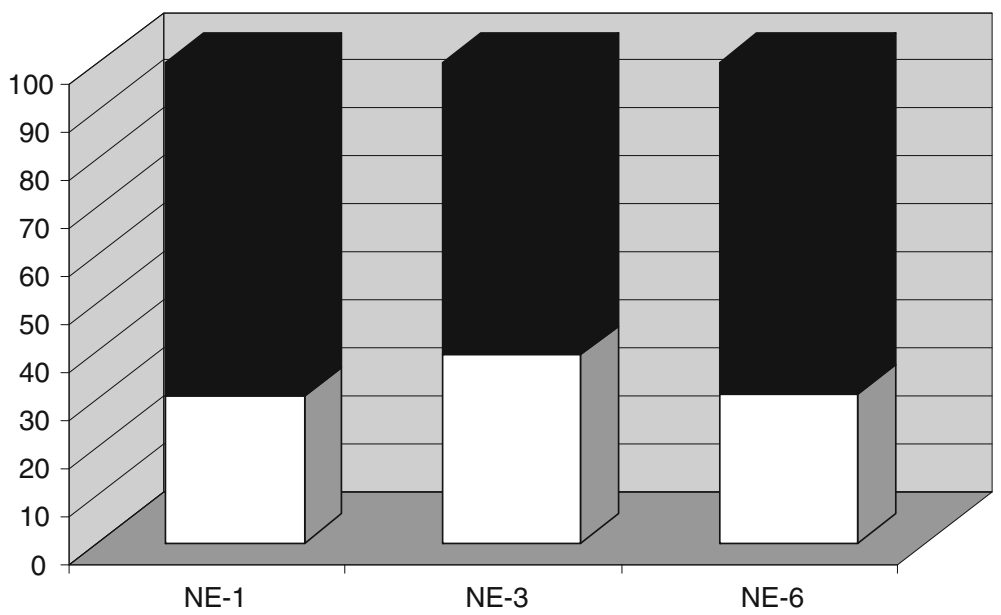

Figure 3. Distribution of serving wares between NE-1, NE-3, and NE-6

group by blocking the previously open eastern extent of the group's patio. Structure 4 included the interment of two burials, a crypt in the center of the structure (Burial C10) and a cist dug into patio fill underlying the structure's staircase (Burial C3). The latter burial is distinct from other burials excavated at the Northeast Group, as it is only one of two burials that contain grave goods. This included a piece of polished jade, two cut shell beads, and a fragment of bivalve shell.

At NE-3, additions were made over the course of 5 additional phases. Phase 2 is defined by the addition of a larger rectangular platform, which would have capped Phase 1, raising the platform approximately $30 \mathrm{~cm}$ in height. Three special deposits, a cache and two burials, were identified in association with this construction phase. Special Deposit 5 was a cache of two sets of lip-to-lip ceramic vessels covered by a plate. Both burials were crypt constructions, each lying underneath the fill associated with this phase of construction. One of these (Burial C5), included burial goods, specifically 23 Marginella shell beads and 2 shell disc-shaped ornaments (Strombus sp.).

Subsequent constructions focused on the development of Structures 2 and 3-Phases 3 and 4, which includes the founding of and later additions to the two structures and Phases 5 and 6, focused on the increase in height and width of Structure 2. A second major deposit was recovered apart of excavations that exposed Phase 4 construction. Prior to resurfacing the 


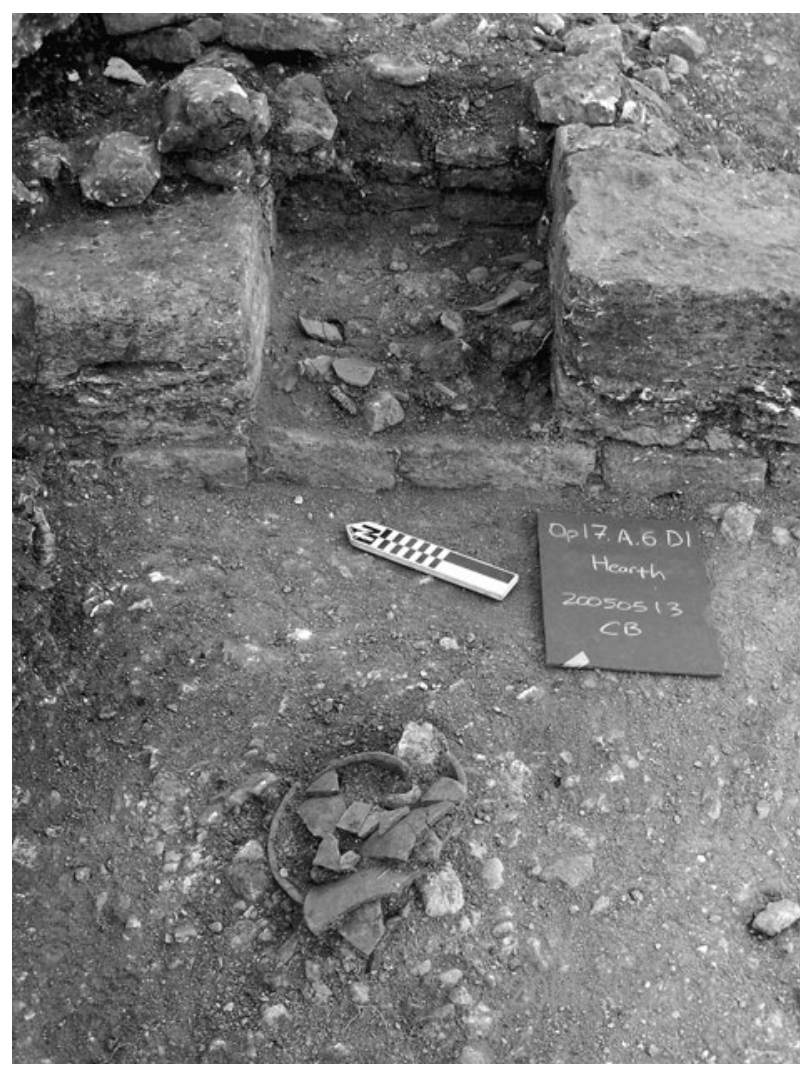

Figure 4. Hearth feature $X$

patio surface during Phase 4 construction, residents deposited and capped ceramic vessels and food bone within a hearth feature built into the western retaining wall of Structure 3 (Figure 4). The deposit included burnt deer and peccary bone, shell fragments, ceramic and lithic fragments, two stacked ceramic dishes, and a $20 \mathrm{~cm}$ lens of ash. The entire deposit was capped by a plaster floor, the group's penultimate patio surface. In association with the group's terminal occupation (Phase 6), shell artifacts were identified from the alleyway between Structures 2 and 3. These include 2 unworked fragments of conch columella, 2 Olivela tinklers, 4 conch ornaments, 1 Marginella shell bead, and 1 shell pendant (Figure 5).

In contrast to NE-1 and NE-3, NE-6 construction was less elaborate with terminal architecture completed in one final addition. Structure 2 was raised an additional $35 \mathrm{~cm}$ which included the addition of a single step and the re-plastering of group's shared patio surface. Additionally, a new 


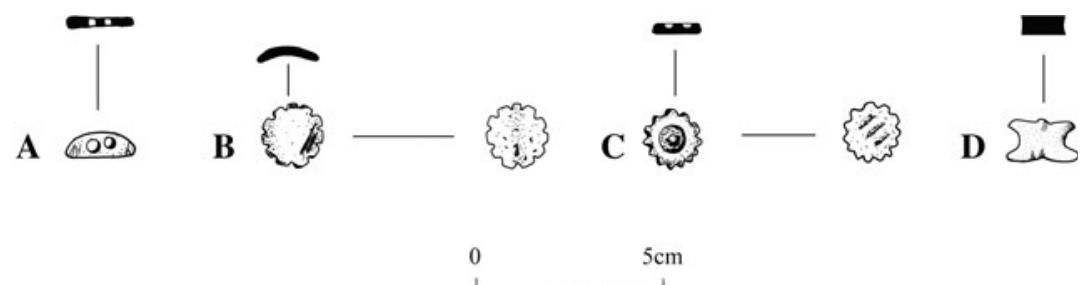

Figure 5. Worked shell artifacts, NE-3 alleyway (drawn by C. Ting \& C. Blackmore) $X$

structure (Structure 1) was built, a small, $20 \mathrm{~cm}$ high platform, approximately $4 \mathrm{~m}$ long $(\mathrm{N}-\mathrm{S})$. Two more deposits were associated with this final construction phase, a crypt burial (Burial C8), identified underlying the additions to Structure 2 and a deposit of human bone fragments (Burial C2) underlying the ultimate patio surface.

\section{Queering Commoner Identities}

I began this article asking whether a queer archaeology requires an analysis of gender or sexuality and if not, how such examinations are themselves "queer". Constructions of "commoner" are part of a dichotomized binary; one structured in opposition to the identities and practices of the elite. Both feminist and queer theorists have long critiqued such dichotomies as Eurocentric, androcentric, and heterosexist. These formulations create unspoken hierarchies in which some categories are marked as different or less then while those that remain unmarked are naturalized (eg. male/ female, public/private, active/passive; straight/gay). Although scholars have critiqued essentialized narratives of ancient maya commoners, archaeological foci continues to equate these groups to modern-day peasant socities-unchanging repositories of tradition and communal culture. In contrast, elites become the political and public face of Maya society and by default the focus of archaeological reconstructions and interpretations (for exceptions see Iannone and Connell 2003; Lohse and Valdez 2004; Robin 1999, 2004; Yaeger 2000).

Research at the Northeast Group illustrates that households occupants were much more than the sum of their productive activties; instead the organization of space, elaboration of architecture, access to long-distance trade, and incorporation of ritually-potent symbols reflect the complex set of practices associated with identity-making. Residents of NE-3 and NE-1, in particular, used ritual practice to distinguish themselves socially from their neighbors. While evidence of ritual was identified throughout the Northeast Group, it was particularly abundant at NE-3; characterized by 
the numerous burials, deposits, evidence of feasting, and utilization of marine shell. The intensity and type of practices recovered suggest that ritual was a public performance, meant for the settlement community at large rather than family or household consumption. In contrast to the visible displays of NE-3, materials from NE-1, four jade fragments and three marine shell objects generally associated with tropes of rulership, fertility, and authority, were found in the private contexts of burials. Because of NE-1's spatial organization, practices involving this material would have been private and not readily viewed by those living outside of the group. Those at NE-3, in comparison, would have been more visible as structures only blocked the northern and southern views into the group.

The diversity of commoner settlements becomes increasingly dynamic when we look at how these same households changed over time. The differences in these materials, spaces and associated practices speak to each household's identity and position within the neighborhood. NE-1 was founded in the Early Classic (200-600 AD) while NE-3 was founded in the first half of the Late Classic period (600-670 AD). For Maya archaeology, the correlation between historical memory and power is generally referred to as the Principal of First Occupancy- the idea that founders retain and define a historically established status invested in the memory of their access, and re-inscribed via the ritual and social acts associated with ancestor commemoration (McAnany 1995). The spatial distribution of NE-1 reflects commonly held notions of how first founder groups change through time; as the population increases, so does the number of residential structures. Thus, the final composite of the group reflects aggregate growth rather than a tightly organized, less-dispersed model (akin to NE-6 and NE-3). While ancestor commemoration was practiced at Group NE-1, it was conducted on a larger scale at NE-3. With the Principle of First Occupancy, such examples are traditionally associated with the founders, not later settlers. As late arrivals to the neighborhood, occupants of NE-3 appear to have appropriated ritual tropes and materials as a means of defining their identity or legitimizing their presence in the neighborhood. Their power was invested primarily in the visible acts of personal adornment and public ritual displays (eg. Graeber 2001). In contrast, residents of NE-1 appear to access private/hidden forms of value through the caching and depositing of jade and shell beads. Although these items were removed from circulation, the memories attached to them provided residents an identity associated with the materials' history, acts that would have reinforced their connection to the past as the neighborhood's founders. In essence, those living at NE-1 had a historical authority and identity that did not require overt public performance 
while those at NE-3 needed visibility to legitimate them within the neighborhood's social structure.

The overt material statements and social practices of NE-3 suggest that occupants were religious specialists. Perhaps religious ideology was utilized to insert these members into the community during a time of population growth and increasing political instability in the surrounding region. In a similar manner, residents at the site of San Lorenzo displayed their connection to Xunantunich elites by using and wearing exotic items and hosting feasts in an effort to differentiate themselves from fellow community members (Yaeger 2000). Changes in social positions and statuses of residents, whether at San Lorenzo or Chan, demonstrate that diversity is a contextual process. The earliest founders of the Northeast group began as "simple" farmers, with household practices associated primarily with farming, storage and production. Once we move into the Late Classic, movements in people and practices changed the dynamics of settlement and social organization.

\section{Conclusions}

Commoner identity is a fluid and contextual social practice; one defined by the social aspirations of individuals and the economic, and political dynamics of community and culture. Within the small scale setting of a neighborhood, identities transformed through time and were invariably affected by other positionalities—class being only one of many. The changes in construction, materials and practices associated with each group demonstrate not only the variability of social identities across a neighborhood but how these grew, changed and were redefined over time and in relationship to competing discourses within the Northeast Group.

As the preceding discussion demonstrates, a queer perspective is not limited to questions of sexuality and gender. While I hope this research will eventually include such analyses, queer theory provides a framework for deconstructing traditional models of ancient Maya social organization. In its ability to deconstruct and denaturalize assumed binary oppositions, queer theory has much to offer Maya archaeology. As demonstrated above, it reminds us that any identity, commoner or otherwise, is not a simple by product of class formation. Commoners were more than the sum of their productive abilities. Rather, they included a wide array of identities and statuses that crosscut kin-groups, class positions, genders, and occupations.

Queering archaeology is a definitive feminist practice. As a "pervasive and persistent questioning of heteronormative assumptions about culture", queer theory provides a necessary critique of archaeological method and theory (Wylie 2004). By dissecting the internal workings of society, the past 
becomes a reflection of reality rather than the "unitary, illusory subject" that only exists in textbooks (Joyce 2005b:307). Standpoint theory, feminist and post-colonial critiques have recognized that science itself is contextual and as such necessitates a critical response from those who exist on the margins of society. In a similar manner, "queering" the past forces us to interrogate our own assumptions and situated identities. Without such critical examinations, archaeology remains an antiquarian pursuit, rather than an emancipatory practice-one that situates our epistemologies and refocuses our discussion to an analysis of difference.

\section{Acknowledgments}

Funding for this project was made available by the National Science Foundation, Sigma-Xi, the University of California, Riverside Graduate Division, and the University of California Office of the President. Work at the Chan site was conducted with permission and support of the Belize Institute of Archaeology. I would like to thank Wendy Ashmore, Christina Halperin, Rosemary Joyce, and Barbara Voss for their comments. As well, I thank the editors, Suzanne Spencer-Wood and Laura Jane Smith, for inviting me to participate in this special edition. Last but never least, I owe Shankari Patel a huge debt for all of her help and her enduring patience. Of course, all errors are my own.

\section{Open Access}

This article is distributed under the terms of the Creative Commons Attribution Noncommercial License which permits any noncommercial use, distribution, and reproduction in any medium, provided the original author(s) and source are credited.

\section{References}

Alberti, B.

2001. Faience Goddesses and Ivory Bull-Leapers: The Aesthetics of Sexual Difference at Late Bronze Age Knossos. World Archaeology 33:189-205.

Anzaldúa, G.

1991. To(o) queer the writer: loca, escrita y chicana. In InVersions: Writings by Dykes, Queers and Lesbians, edited by B. Warland. Press Gang, Vancouver, pp. 249-263. 
Ardren, T.

2008. Studies of Gender in Prehispanic Americas. Journal of Archaeological Research 16:1-35.

Ashmore, W., and R. M. Leventhal

1993. Xunantunich Reconsidered. Paper presented at the Belize Conference, University of North Florida, Jacksonville.

Ball, J.W., and J.T. Taschek

1991. Late Classic Lowland Maya Political Organization and Central-Place Analysis: New Insights from the Upper Belize Valley. Ancient Mesoamerica 2(2):149-166.

Barnard, I.

1999. Queer Race. Social Semiotics 9(2):199-212.

Blackmore, C.

2007. Commoner Ritual and Socio-political Life in a Late Classic Neighborhood: Archaeological Investigations at the Northeast Group, Chan, Belize. In Papers of the 2006 Belize Archaeology Symposium, edited by J. Awe, J. Morris, S. Jones, and C. Helmke. Institute of Archaeology, Belmopan, Belize, pp. 24-46.

2008. Challenging "Commoner": An Examination of Status and Identity at the Ancient Maya Village of Chan, Belize. Ph.D. Dissertation. Department of Anthropology, University of California, Riverside. Microfilms, Ann Arbor.

In Press. Ritual Among the Masses. Latin American Antiquity.

Butler, J.

1990. Gender Trouble: Feminism and the Subversion of Identity. Routledge, New York.

1993. Bodies That Matter: On the Discursive Limits of "Sex". Routledge, New York.

Casella, E.C.

2000. Doing trade: A Sexual Economy of Nineteenth-Century Australian Female Convict Prisons. World Archaeology 32:209-221.

Casella, E.C., and C. Fowler (editors)

2005. The Archaeology of Plural and Changing Identities: Beyond Identification. Kluwer/Plenum, New York.

Chase, A.F., and J.F. Garber

2004. The Archaeology of the Belize Valley in Historical Perspective. In The Ancient Maya of Belize Valley: Half a Century of Archaeological Research, edited by J.F. Garber. University Press of Florida, Gainesville, pp. 1-14.

Croucher, K.

2005. Queerying Near Eastern Archaeology. World Archaeology 37:610-620. 
De Lauretis, T.

1991. Queer Theory: Lesbian and Gay Sexualities: An Introduction. Differences: A Journal of Feminist Cultural Studies 3.2:iii-xviii.

Docster, E., S. Juarez, A. Wyatt, and C. Robin

2008. A Changing Cultural Landscape: Settlement Survey and GIS at Chan. Paper presented at the 73rd Annual Meeting of the Society for American Archaeology, Vancouver, Canada.

Dowson, T. A.

1998. Homosexualitat, teortia queer i arqueologia. Cota Zero 14:81-87.

2000. Why Queer Archaeology? An Introduction. World Archaeology 32(2): 161-165.

2007. Archaeologists, Feminists and Queers: Sexual Politics in the Construction of the Past. In Feminist Anthropology: Past, Present, and Future edited by P. L. Geller and M. K. Stockett. University of Pennsylvania Press, Philadelphia, pp. 89-102.

Foucault, M.

1978. The History of Sexuality. Volume I: An Introduction. Random House, New York.

Gifford, James C.

1976. Prehistoric Pottery and the Ceramics of Barton Ramie in the Belize Valley. Papers of the Peabody Museum of Archaeology and Ethnology, Vol. 18. Harvard University, Cambridge, MA.

Gonlin, N.

1994. Rural Household Diversity in Late Classic Copan, Honduras. In Archaeological Views from the Countryside: Village Communities in Early Complex Societies, edited by G.M. Schwartz, and S.E. Falconer. Smithsonian Institution Press, Washington D.C., pp. 177-197.

Graeber, D.

2001. Toward an Anthropological Theory of Value: The False Coin of Our Own Dreams. Palgrave Macmillan, New York.

Grosz, E.

1994. Volatile Bodies: Toward a Corpreal Feminism. Allen \& Unwin, Sydney.

Halperin, D.

1995. Saint Foucault: Towards a Gay Hagiography. Oxford University Press, Oxford.

Hammonds, E.

1997. Black (W)holes and the Geometry of Black female Sexuality. In Feminism Meets Queer Theory, edited by E. Weed, and N. Schor. Indiana University Press, Bloomington, pp. 136-156. 
Harding, S.

1991. Whose Science? Whose Knowledge? Thinking from Women's Lives. Cornell University Press, Ithaca.

Hays-Gilpin, KA.

2004. Ambiguous Images: Gender and Rock Art. AltaMira, Walnut Creek, Ca.

Hollimon, S.E.

1997. The Third Gender in Native California: Two-Spirit Undertakers among the Chumash and their Neighbors. In Women in Prehistory: North American and Mesoamerica, edited by C. Claassen, and R.A. Joyce. University of Pennsylvania Press, Philadelphia, pp. 173-188.

Iannone, G., and S. V. Connell (editors)

2003. Perspectives on Ancient Maya Rural Complexity, Monograph 49. The Cotsen Institute of Archaeology, Los Angeles.

Joyce, R.A.

2000. Girling the Girl and Boying the Boy: the Production of Adulthood in Ancient Mesoamerica. World Archaeology 31:473-483.

2004. Embodied Subjectivity: Gender, Femininity, Masculinity, Sexuality. In A Companion to Social Archaeology, edited by L. Meskell, and R.W. Preucel. Blackwell, Oxford, pp. 82-95.

2005a. Archaeology of the Body. Annual Review of Anthropology 34:139-158.

2005b. What Kind of Subject of Study is "The Ancient Maya"? Reviews in Anthropology 34:295-311.

LeCount, L.

2001. Like Water for Chocolate: Feasting and Political Ritual among the Late Classic Maya at Xunantunich, Belize. American Anthropologist 103(4):935953.

LeCount, L., J. Yaeger, R.M. Leventhal, and W. Ashmore

2002. Dating the Rise and Fall of Xunantunich, Belize. Ancient Mesoamerica 13:41-63.

Leventhal, R.M., and W. Ashmore

2004. Xunantunich in a Belize Valley Context. In Archaeology of the Belize Valley: Half a Century of Maya Settlement Studies, edited by J. Garber. University Press of Florida, Gainesville, pp. 168-179.

Lohse, J. C., and F. C. Valdez

2004. Examining Ancient Maya Commoners Anew. In Ancient Maya Commoners, edited by J. C. Lohse, and F. C. Valdez. University of Texas Press, Austin, pp. 1-21.

Loren, D.

2001. Social Skins: Orthodoxies and Practices of Dressing in the Early Colonial Lower Mississippi Valley. Journal of Social Archaeology 1:172-189. 
Martin, S., and N. Grube

2000. Chronicle of the Maya Kings and Queens: Deciphering the Dynasties of the Ancient Maya. Thames and Hudson, New York.

McAnany, P. A.

1995. Living with the Ancestors: Kinship and Kingship in Ancient Maya Society. University of Texas Press, Austin.

Meskell, L.M.

1999. Archaeologies of Social Life: Age, Sex, Class et cetera in Ancient Egypt. Blackwell, Oxford.

2007. Refiguring the Corpus at Catalhoyuk. In Material Beginnings: A Global Prehistory of Figurative Representation, edited by C Renfrew, and I. Morley. McDonald Institute, Cambridge, pp. 143-156.

Meskell, L.M., and R.A. Joyce

2003. Embodied Lives: Figuring Ancient Maya and Egyptian Experience. Routledge, London.

Moraga, C.

1996. Queer Aztlan: the Re-formation of Chicano tribe. In The Material Queer: A LeBiGay Cultural Studies Reader, edited by D. Morton. Westview Press, Boulder, pp. 297-304.

Nagel, J.

2000. Ethnicity and Sexuality. Annual Review of Sociology 26:107-133.

Namaste, K.

1996. Tragic Misreadings: Queer Theory's Erasure of Transgender Subjectivity. In Queer Studies: A Lesbian, Gay, Bisexual, and Transsexual Anthology, edited by B Beemyn, and M Eliason. New York University Press, New York, pp. 183-203.

Ortner, S., and H. Whitehead

1981. Sexual Meanings: The Cultural Construction of Gender and Sexuality. Cambridge University Press, New York.

Perry, E.M., and R.A. Joyce

2001. Providing a Past for "Bodies That Matter": Judith Butler's Impact on the Archaeology of Gender. International Journal of Sexuality and Gender Studies 6:63-76.

Robin, C.

1999. Towards an Archaeology of Everyday Life: Maya Farmers at Chan Noohol and Dos Chombitos Cik'in, Belize. Ph.D Dissertation, University of Pennsylvania.

2003. New Directions in Classic Maya Households Archaeology. Journal of Archaeological Research 1(4):307-356. 
2004. Social Diversity and Everyday Life within Classic Maya Settlements, In Mesoamerican Archaeology, edited by J. A. Hendon and R. A. Joyce. Blackwell Publishing, Oxford, pp. 148-168.

Robin, C., A. Wyatt, and C. Blackmore 2005. Summary Statement of the

2005 Chan Project Research. In The Chan Project Report: 2005 Season, edited by C. Robin. Report submitted to the Institute of Archaeology, Belize, pp. $85-96$.

Robin, C., J. Meierhoff, C. Kestle, C. Blackmore, and C. Hetrick

2008. A 2000 Year History of Ritual in a Farming Community. Paper presented at the 73rd Annual Meeting of the Society for American Archaeology; Vancouver, Canada.

Robin, C., C. Blackmore, and M. Latsch

2003. Household and Community Ritual in a Maya Farming Community: The 2003 Season at the Chan Site. In Archaeological Investigations in the Eastern Maya Lowlands: Papers of the 2004 Belize Archaeology Symposium, Research Reports in Belizean Archaeology, edited by J. Awe, J. Morris, S. Jones and C. Helmke, pp. 339-349. Institute of Archaeology, Belmopan, Belize.

Rubin, G.

1984. Thinking Sex: Notes for a Radical Theory of the Politics of Sexuality. In Pleasure and Danger: Exploring Female Sexuality, edited by C.S. Vance. HarperCollins, New York, pp. 267-319.

Rudy, K.

2000. Queer Thoery and Feminism. Women's Studies 29:195-216.

Schmidt, R.A.

2002. The Iceman Cometh: Queering the Archaeological Past. In Out in Theory: The Emergence of Lesbian and Gay Anthropology, edited by E. Lewin, and W.L. Leap. University of Illinois Press, Chicago, pp. 155-185.

Schmidt, R. A., and B. L. Voss (editors)

2000. Archaeologies of Sexuality. Routledge, London.

Sedgwick, E. K.

1990. Epistemology of the Closet. University of California Press, Berkeley.

Sullivan, N.

2003. A Critical Introduction to Queer Theory. New York University, New York.

Strassburg J.

2000. Shamanic Shadows: One Hundred Generations of Undead Subversion in Southern Scandinavia, 7,000-4,000 BC. Stockholm University Studies in Archaeology, Stockholm.

Voss, B. L.

2000. Feminisms, Queer Theories, and the Archaeological Study of Past Sexualities. World Archaeology 32(2):180-192. 
2005. Sexual Subjects: Identity and Taxonomy in Archaeological Research. In The Archaeology of Plural and Changing Identities: Beyond Identification, edited by E.C. Casella, and C. Fowler. Kluwer/Plenum, New York, pp. 5578 .

2008. Sexuality Studies in Archaeology. Annual Review of Anthropology 37:317336.

Voss, B. L., and R. A. Schmidt

2000. Archaeologies of Sexuality: An Introduction. In World Archaeology, edited by R. A. Schmidt, and B. L. Voss. Routledge, London, pp. 1-35.

Weedon, C.

1999. Feminism, Theory and the Politics of Difference. Blackwell Publishers, Oxford.

Wyatt, A.

2004. Operation 4. In The Chan Project Report: 2003 Season, edited by C. Robin, Report submitted to the Institute of Archaeology, Belize.

2008. Agricultural Practices at the Chan Site: Farming and Political Economy in an Ancient Maya Community. Paper prepared for the Society for American Archaeology 73rd Annual Meeting, Vancouver, British Columbia, Canada.

Wylie, A. 2004. Keynote Address: Que(e)rying archaeology. Paper presented at the 2004 Chacmool Conference, University of Calgary, Calgary, Alberta.

Yaeger, J.

2000. The Social Construction of Communities in the Classic Maya Countryside: Strategies of affiliation in western Belize. In The Archaeology of Communities: A New World Perspective, edited by M. Canuto, and J. Yaeger. Routledge, London, pp. 123-142.

Zinn, M.B., and B.T. Dill

1996. Theorizing Difference from Multiracial Feminism. Feminist Studies 22(2):321-331. 